\title{
Application of Problem-Based Learning to Enhance Student Learning Outcomes in Basic Competencies of Maintaining Brake Systems
}

\author{
Wahid Munawar * \\ Email : wahidmunawar@upi.edu * \\ *: coresponndensing author \\ Universitas Pendidikan Indonesia Street Dr. Setiabudhi No. 207 Bandung 40154, Indonesia
}

Article history

Received Mar 14, 2021

Revised May 21, 2021

Accepted May 31, 2021

Keywords

Assessment of Competency

Dichotomy scoring

Vocational of automotive
Assessment of competency in schools is carried out by teachers using conventional tests, consists of multiple choice tests, essay tests, and skills tests using open scoring competency tests based on the teacher's principle of "being in charge" in scoring. Therefore, a assessment of competency tool is needed that measures the real competence of students. The research objective was to diagnose students' skills in automotive body vocational learning through a dichotomy scoring competency test. The research method used is pre experimental design (non designs) one shot case study. The research was conducted in January-March 2020. The research location was in a state vocational high school in Bandung. The research sample used simple random sampling of 32 students. Data collection used a dichotomy scoring skill test. Data analysis using percentages. The results showed that: (1) $84 \%$ of the students were not competent in the competence of automotive bodies in making mini cars when using the dichotomy scoring competency assessment; (2) only $16 \%$ of students were able to complete the competency test by producing work products that match dimensions and on time.

This is an open access article under the CC-BY-SA license.

\section{Introduction}

Assessment of the learning process uses an authentic assessment approach which assesses the readiness of students, the process, and learning outcomes as a whole. The integration of the assessment of the three components will describe the capacity, style, and learning acquisition of students who are able to produce an instructional effect on the knowledge aspect and the nurturant effect on the attitude aspect. The results of the authentic assessment are used by the teacher to plan remedial learning, enrichment, or counseling services.

The preliminary observations on automotive body vocational learning in one class at a state vocational high school in Bandung show that $98 \%$ passed the competency test, while $2 \%$ failed because they did not take the competency test. The results of this competency test contradict the data on the learning outcomes of subjectteachers, because when using a standard competency 
test, $55 \%$ of students do not pass the competency test. In fact, the competency test does not reflect the competence of students. The different competency test results are suspected to be due to invalid competency test kits and the inability of teachers to make valid competency assessments.

Assessment of competency in schools is carried out by teachers using conventional tests, namely multiple choice tests, essay tests, and skills tests using open scoring competency tests based on the teacher's principle of "being in charge" in scoring. Therefore, a competency assessment tool is needed that measures the real competence of students.

One of several factors related to vocational education quality standards is the effectiveness of learning, which includes assessment of learning outcomes. Learning outcomes (what is learned in school) are indicators of vocational education as a provider of the labor market. The measured learning outcomes are cognitive abilities, attitudes and values (character) and skills.

The reality in this vocational high school, shows that the assessment of learning outcomes emphasizes the use of written assessment instruments (paper and pencil tests) and assessments of skills knowledge (knowledge of performance) rather than authentic assessment in the form of performance tests. This is one factor in the low level of relevance of vocational education outcomes, namely the mismatch between educational programs and employment demands.

In theory learning, the assessment used by the teacher at the time of evaluation tends to be in the realm of Lower Order Thinking Skills (LOTS). This phenomenon is not only a local problem, but has entered the global realm. There is international concern about the dominance of the LOTS assessment practice which only encourages students to focus on learning that emphasizes memorization (Osborne \& Dillon, 2008).

The impact of these various problems is that graduates lack thinking skills to solve problems that arise in everyday life as well as the inability of graduates to compete in the relevant world of work. Alternative problem solving is the development of assessments that can encourage students to think broadly and deeply and shape students to become effective communicators, critical and dynamic thinkers, creative and competent problem solvers (ŽivkoviL; 2016).

In practical or skill learning, the teacher uses a test-form psychomotor assessment with open assessment. Student learning outcomes are determined by the teacher with the teacher's own will, so that student learning outcomes do not reflect student competencies. The assessment produces competencies that are not original. To prevent assessment bias by teachers, a fair competency assessment is needed and truly reflects the original competence of students.

Therefore, it is necessary to research, "Competency Assessment Based on Dichotomy Scoring to Diagnose Student Skills in Automotive Body Vocational Learning".

The formulation of the problem in this study are; (1) How can the dichotomy scoring competency test diagnose the skills of students in the automotive body vocational field?; (2) How 
is the diagnosis of the student's ability in preparation, process and product for automotive body vocational work through the assessment of the competency scoring dichotomy .

\section{Method}

\section{Assessment of Competency Based on Dichotomy Scoring}

The essence of vocational education is the ownership of competencies in students that are relevant to the world of work, so they can work professionally. Professionalism in education needs to be interpreted as "he does his job well", which means that individuals who gain recognition have the competency of the type and level of expertise in the professional field in accordance with the applicable requirements in their professional field (Munawar, 2018).

Competence is defined as the ability to apply knowledge, thinking skills (logical, intuitive, and creative) and practical (including the ability to do something carefully and accurately by applying methods, materials, tools and instruments) in line with scientific field and expertise.

Competency testing is essentially an assessment activity and making decisions whether a person is competent or not in one scope of work. This is in accordance with the opinion of Salvia in Munawar (2018), consist of: assessment is the process of collecting data for the purpose of (1) specifying and verifying problems and (2) making decisions about student. Competency assessment is defined as an assessment or evaluation which is based on knowledge, skills and work attitudes to carry out a job task.

The assessment is carried out as a step to evaluate the performance of the entire system, analyze the effectiveness of teaching, and obtain information in order to make decisions about students, curriculum, and educational policies aimed at improving the quality of learning (Usoof, 2012; Abosalem, 2016). Another function of the assessment is to provide information and control the quality of education, which includes all components of education from the implementation process to educational products (Yusuf, 2015). It should be noted that assessment is not only used for the learning process, but also motivates students to learn.

Assessment in the context of skills (psychomotor domain), according to Bott in Munawar (2018) includes: observation, imitation, practice, adaptation. Observation competence, for example: in motor vehicle service competence, students must make observations, namely: looking for sources of interference on the motorbike, finding the cause of the disturbance, observing the engine. Imitation or imitation competencies, for example: students draw workpieces, demonstrate machine operation. Competence to practice, for example: repairing damaged machines, replacing repaired components, operating computers. Adaptation competencies, for example: creating design and manipulation of work procedures. Skills tests include two directions, consist of: work processes (procedures) and work results (products). 
In the following, an example of a dichotomy scoring competency assessment is as follows on Figure 1:

\begin{tabular}{|c|c|c|c|c|}
\hline \multicolumn{5}{|c|}{ 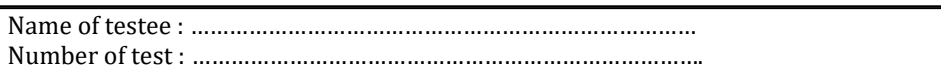 } \\
\hline \multicolumn{5}{|c|}{$\begin{array}{l}\text { Instructions: } \\
\text { Write tick (V) for the test taker's observed ability during the performance test }\end{array}$} \\
\hline \multicolumn{5}{|c|}{$\begin{array}{l}\text { SKILL TEST MATERIAL: PIPING IN THE REFRIGERATION SYSTEM } \\
\text { SUB COMPETENCY } \quad: \text { NO. 1. BENDING COPPER TUBING }\end{array}$} \\
\hline \multicolumn{5}{|c|}{$\begin{array}{l}\text { Objective: } \\
\text { Able to work on and produce bendingcopper tubing products (bending pipes) in } \\
\text { refrigeration and air conditioning (AC) systems. }\end{array}$} \\
\hline \multirow[t]{2}{*}{ No } & \multirow[t]{2}{*}{ Indicator } & \multirow[t]{2}{*}{ Visual of work } & \multicolumn{2}{|c|}{ Scoring } \\
\hline & & & $\begin{array}{l}\text { Yes } \\
\text { (1) }\end{array}$ & No $(0)$ \\
\hline & $\begin{array}{l}\text { A. Design of Work: } \\
\text { 1. K3 preparation: } \\
\text { a. Work uniform } \\
\text { b. Physical Health } \\
\text { c. Work Identity } \\
\text { 2. Material Preparation } \\
\text { a. } 1 / 4 \text { "diameter copper pipe, } \\
\text { length } 30 \mathrm{~cm} \\
\text { 3. Preparation of work tools } \\
\text { a. Bending tools }\end{array}$ & 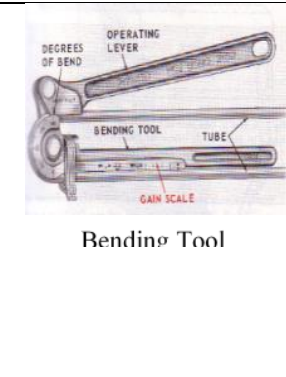 & 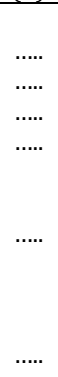 & 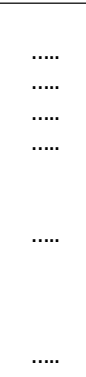 \\
\hline & $\begin{array}{l}\text { B. WORK PROCESS } \\
\text { 1. Measure the pipe } \\
\text { 2. Cut the pipe using a tube } \\
\text { cutter to size }\end{array}$ & & $\cdots$ & $\cdots$ \\
\hline
\end{tabular}

Figure 1. Scoring Competency Assessment (Munawar, 2018)

\section{Assessment of competency and diagnosis of automotive body learning outcomes}

Vocational learning has a character, consist of education for earning a living and education for work (Bukit, 2014). After graduating from school, students are prioritized to work in the world of economy.

Vocational institutions, especially vocational schools (SMK) in Indonesia, have not formed graduates who have two balanced skills between hard skills and soft skills (Wibowo, 2016). This is related to the educational process in schools, where students get more hard skills but forget about soft skills, so that in general the weaknesses of vocational high school graduates in filling job opportunities lies in the problem of personal skills. It is pointed out that there is a difference in goals between the world of education and the industrial world because the world of education wants graduates who have high scores in a fast time, while the industrial world wants graduates with technical competence and good attitude.

Automotive body learning has learning characteristics that emphasize the ability of hard skills and soft skills. In automotive body knowledge, they are expected to apply tools and practical materials for automotive body work when practicing automotive body. In automotive body practice, students are expected to have skills in work processes and produce work products that 
have quality and time standards.

Automotive body vocational learning -the skills to make mini cars- consists of work: work preparation (tools and materials), work processes and work products. The types of competencies that are expected to be mastered by students are the ability to: (1) prepare work tools; (2) preparing work materials; (3) making body molds; (4) mold the chassis; (6) making wheel molds; (7) produce mini car products according to quality and time standards.

Educational assessment will be meaningful in providing precise and accurate information if it meets the criteria as a good and correct instrument, is properly administered and is objectively processed based on appropriate and supposed criteria (Yusuf, 2015).

A good assessment should meet the validity and reliability requirements. The instrument is said to be valid (has high validity), if the tool is able to measure and assess what you want to measure and assess. Therefore, the validity of an instrument refers to the accuracy of an instrument in assessing what it wants to assess. The accuracy and meaning is concluded based on the evidence of each individual's instrument score (the subject being assessed). The validity to be measured includes content validity and construct validity. The content validity functions to check the suitability between the test items made with the indicators, materials or learning objectives that have been set. Construct validity is to check how precisely the concepts reflected in the test items match the actual test intent on a measuring device (Susetyo, 2015). The reliability of an instrument refers to the accuracy, consistency, or stability of the instrument (the measurements taken). The instrument is said to be reliable if the measuring instrument is tested on the same object / subject repeatedly, the results will remain the same, consistent, stable or relatively the same (not statistically different) (Susetyo, 2015).

Although there are many ways to measure learning success, the most commonly used method is "occupational competency testing" which is designed to measure mastery of skills and knowledge found in a particular job.

Diagnosis of learning outcomes in automotive body vocational learning - the skills to make mini cars - consists of work: work preparation (tools and materials), work processes and work products. The types of competencies that are expected to be mastered by students are the ability to: (1) prepare work tools; (2) preparing work materials; (3) making body molds; (4) mold the chassis; (6) making wheel molds; (7) produce mini car products according to quality and time standards.

\section{Research Methods}

This research used pre-experimental design (non designs) one shot case study. In this study, a group was given treatment and the results were observed. The treatment was given to a group of class on the second level students of the automotive study program in the automotive body 
subject. The form of treatment is the use of a dichotomy scoring competency assessment or a competency test (success-failure). The research data is the learning outcomes of students who take the competency test using dichotomy scoring.

The research was conducted in January-March 2020. The research location was in a state vocational high school in Bandung. The population was students of class IIA automotive study program with 3 (three) classes, while the research sample used simple random sampling, selected 32 students of class IIA automotive study program. The research sample was tested using a dichotomy scoring competency test, then the results of the competency test were seen. Observations were made to diagnose the learning outcomes of competency test participants. Testing is a direct observation by the researcher. Data collection used a dichotomy scoring skill test. The following is a research instrument for assessing the competency of the automotive body vocational dichotomy scoring. It shown on Table 1.

Table 1. Assessment of the vocational competence of the automotive body with a dichotomy

\begin{tabular}{|c|c|c|c|}
\hline \multirow[t]{2}{*}{ Assessment of competency } & \multicolumn{2}{|c|}{$\begin{array}{l}\text { Scoring of } \\
\text { dichotomy }\end{array}$} & \multirow[t]{2}{*}{$\begin{array}{l}\text { Number of sub } \\
\text { competencies }\end{array}$} \\
\hline & Yes & No & \\
\hline A.Job preparation skills; & & & 2 \\
\hline 1. Skills to prepare work tools & 1 & 0 & \\
\hline 2. Skills to prepare work materials & 1 & 0 & \\
\hline B.Work process skills: & & & 3 \\
\hline 1. Make a body mold & 1 & 0 & \\
\hline 2. Making the chassis mold & 1 & 0 & \\
\hline 3. Making wheel mold & 1 & 0 & \\
\hline C.Work product skills: & & & 2 \\
\hline $\begin{array}{l}\text { 1.Work products are finished according } \\
\text { to standards (dimensions and quality) }\end{array}$ & 1 & 0 & \\
\hline $\begin{array}{l}\text { 2. Work products completed faster or on } \\
\text { time }\end{array}$ & 1 & 0 & \\
\hline
\end{tabular}

with work readiness competence, work process competence and ending with work product competence. Test participants who fail one sub-competency cannot take the next stage of the competency test.

\section{Result and Discussion}

This research was conducted on a sample of 32 students. Students were given treatment, namely a skill test with dichotomy scoring. The skills test consists of three stages, namely: the work preparation stage, the work process and work products. The decision on the competency test results is competent-incompetent.

The assessor tests the skills of the test takers in stages, in a sequence of tests, consist of: work preparation, work processes and work products. Students are declared to have skills if they are able to demonstrate abilities according to the indicators. Students are declared failures if they 
are unable to demonstrate skills according to the test indicators. Students who are declared failing or incompetent at the test stage, may not continue the next test. Teachers can diagnose student skill levels based on test items.

In the first stage, the competency assessment is a skill test with work preparation indicators, consist of: (1) preparation of working tools for making miniature cars and (2) preparing work materials for making miniature cars. The second stage, competency assessments are carried out in the work process of making miniature cars, and the third stage, competency assessments on work results or work products with product indicators that are made according to standards and products are carried out faster or on time. The results of research in the following Table 2:

Table 2. The results body automotive competency test based on scoring dicothomy

\begin{tabular}{lllc} 
No & \multicolumn{1}{c}{ Item test } & $f$ & $\%$ \\
\hline A. & Work preparation: & 32 & $100 \%$ \\
1. & Preparation of work tools to make a mini car & 30 & $94 \%$ \\
2. & Preparation of work materials to make a mini car & 29 & $91 \%$ \\
B. $\quad$ Work process & & \\
3. & Making body molds & 28 & $88 \%$ \\
4. & Making chassis molds & 18 & $56 \%$ \\
5. & Making wheel molds & 11 & $34 \%$ \\
C. & Work products: & & \\
6. $\quad$ Product results in accordance with product standards & 7 & $22 \%$ \\
7. $\quad$ Product results are made faster or on time & 5 & $16 \%$ \\
\hline
\end{tabular}

Based on the results of the study, it is obtained descriptions, consist of: (1) 16\% of students are competent in automotive body vocational work - making mini cars -; (2) At the stage of making wheel molds and the following comets, only $34 \%$ of students were competent. The low competence of students in the sub-competence of work processes and work products. This means that the teacher needs to diagnose the inability of students in automotive body vocational work that following on Table 3. Based on the data, it is illustrated that: $94 \%$ of students have the ability to prepare work tools for making miniature car crafts, then $91 \%$ of students have the ability to prepare work materials. 
Table 3. Diagnosis of Practical Ability to Prepare Work Tools and Materials

\begin{tabular}{llccc}
\hline Parameter & \multicolumn{1}{c}{ Indicator } & Description & $f$ & $\%$ \\
\hline $\begin{array}{l}\text { Work } \\
\text { preparation }\end{array}$ & Ability to prepare tools & 30 & $94 \%$ \\
& $\begin{array}{l}\text { Ability to prepare } \\
\text { materials }\end{array}$ & & 29 & $91 \%$ \\
& & & & \\
& & & $=32$ & \\
\hline
\end{tabular}

Note: f: frequency of capable / competent students

The results of this study indicate that almost all students (91\%) have job preparation competencies in the automotive body vocational field to make mini cars. The results of this study suggest that the competence of preparing tools and work materials only requires the ability to understand and apply the skills theory presented by the teacher. The results of this study support Nugroho's research (2018) that Indonesian students have the ability to reach the application stage or Lower Order Thinking Skills (LOTS). The LOTS assessment only facilitates students in the realm of short term memory.

Based on the data in table 4, it is illustrated that: $34 \%$ of students have the ability to work processes (make mini cars). The data of this study indicate that $66 \%$ of students are not competent in the work process (making miniature cars). Teachers need to diagnose students' disabilities at this stage of the work process that following on Table 4.

Table 4. Diagnosis of Ability to Practice Doing the Work Process

\begin{tabular}{llccc}
\hline Parameter & Indicator & Description of test & $f$ & $\%$ \\
\hline $\begin{array}{l}\text { Work } \\
\text { process }\end{array}$ & $\begin{array}{c}\text { Ability to make } \\
\text { body mold } \\
\text { Ability to make } \\
\text { chassis mold } \\
\text { Ability to make } \\
\text { wheel mold }\end{array}$ & 28 & $88 \%$ \\
& $\mathbf{n}$ & 18 & $56 \%$ \\
& & & & \\
& & $\mathbf{3 2}$ & \\
\hline
\end{tabular}

Note: f: frequency of capable / competent students

At the final stage of the work process, the sub-competence of making wheel molds, it appears that only $34 \%$ of students have the competence to make mini cars at the work process stage. The results of the diagnosis show the low competence of students at the work process stage of making mini cars. The causative factor is suspected of having an error in the theoretical and practical learning process. 
Based on the data in table 5, the research results obtained that only $16 \%$ of students have the ability to work products (produce mini cars). The data of this study indicate that $84 \%$ of students do not have the competence to make miniature cars. Teachers need to diagnose students' disabilities at the work product stage. At the stage of the ability to produce products according to the dimensions and product quality, $22 \%$ of students are competent, while in the final stage, the ability to produce products according to the standard time remains $16 \%$ of competent students that shown on Table 5.

Table 5. Diagnosis of Practice Ability to Make Work Products

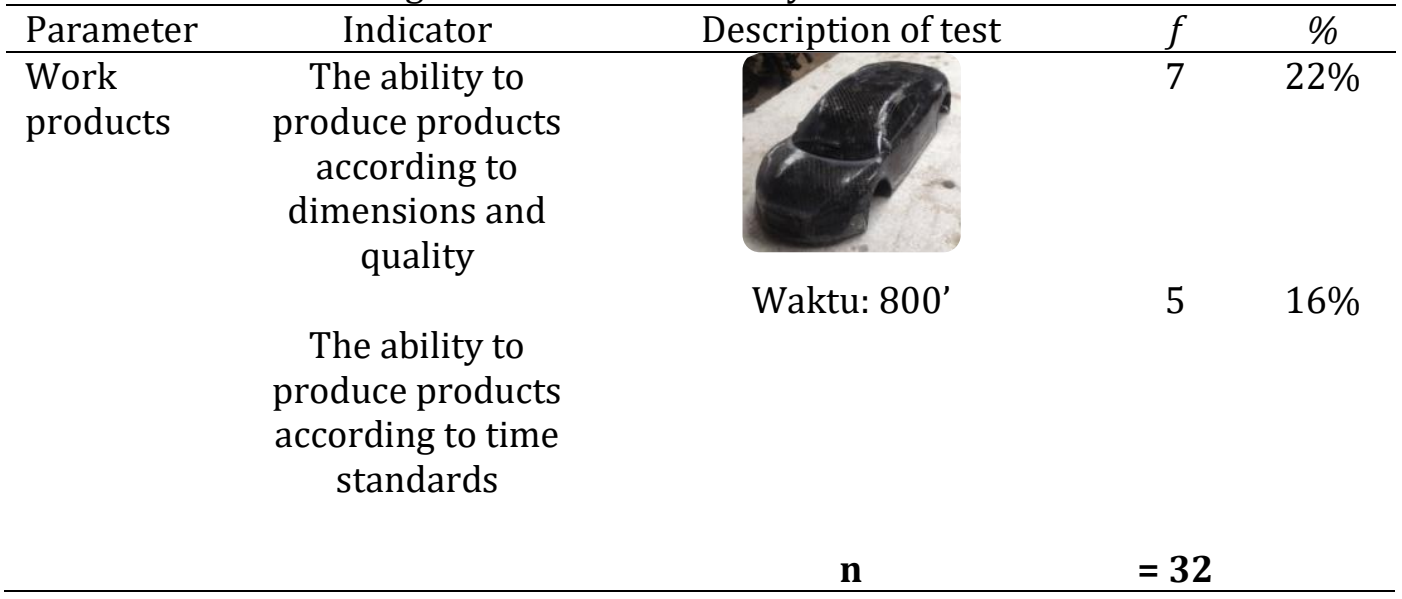

Note: f: frequency of capable / competent students

Based on the research data, it shows that: (1) competency assessment can diagnose sub competencies that are not mastered by students in the automotive body vocational field to make mini cars; (2) competency assessment can determine individual students at the sub-competency stage controlled by students, so that teachers can learn remedial automotive body vocational practices. Teachers also need to reveal the factors that cause students' inability to work products.

The results of the diagnosis of the student's inability to prepare work tools are thought to have the following factors: (1) not understanding automotive craft work; (2) students do not consider the ability to prepare work tools for making automotive crafts; (3) students are not able to understand and apply work materials to automotive crafts.

The results of the diagnosis of the student's inability to carry out the work process indicated that the student was unable to make automotive craft products. This means that there is a need for improvement in the automotive craft learning process. The same thing happens to the skills to produce work products according to product quality and time standards, students are not competent.

Assessment of competency is an assessment of the learning process which is able to produce an instructional effect on the knowledge aspect and the nurturant effect on the attitude aspect. The results of the authentic assessment are used by the teacher to plan the learning remedial program. 


\section{Conclusion}

The conclusions of this study were: (1) the competency assessment based on dichotomy scoring was successful in diagnosing the inability of students in learning the vocational practice of automotive bodies -making mini cars-; (2) Competency assessment based on dichotomy scoring is able to describe the learning outcomes of automotive body vocational practice -making mini cars- at the work preparation stage, work processes and work products.

\section{References}

Abosalem, Y. (2016). Assessment techniques and students' higher-order thinking skills. International Journal of Secondary Education, 4(1), 1.

Bukit, M. (2014). Strategi dan Inovasi Pendidikan Kejuruan [Vocational Education Strategies and Innovations]. Bandung: Alfabeta.

Munawar, W., Adam, R. M. N., \& Sriyono, S. (2018). Development of Performance Assessment Standard Career with Dichotomy Scoring as Competence Test at Vocational School. Proceedings of the 5th UPI International Conference on Technical and Vocational Education and Training (ICTVET 2018).

Nugroho, R. A. (2018). HOTS Kemampuan Berpikir Tingkat Tinggi: Konsep, Pembelajaran, Penilaian dan Soal-soal [HOTS Higher Level Thinking Skills: Concept, Learning, Assessment and Problems]. Jakarta: Gramedia.

Osborne, J., \& Dillon, J. (2008). Science education in Europe: Critical reflections (Vol. 13). London: The Nuffield Foundation.

Susetyo, B. (2015). Prosedur Penyusunan \& Analisis tes [Test Preparation \& Analysis Procedure]. Bandung: PT Refika Aditama.

Usoof, H. (2012). Designing for eAssessment of higher order thinking: An undergraduate IT online distance education course in Sri Lanka. Doctoral dissertation. Umeå University.

Wibowo, N. (2016). Upaya memperkecil kesenjangan kompetensi lulusan sekolah menengah kejuruan dengan tuntutan dunia industry [Efforts to reduce the competency gap of vocational high school graduates with the demands of the industrial world]. Jurnal Pendidikan Teknologi dan Kejuruan, 23(1), 45-59.

Yusuf, M. (2015). Asesmen dan Evaluasi Pendidikan: Pilar Penyedia Informasi dan Kegiatan Pengendalian Mutu Pendidikan [Education Assessment and Evaluation: The Pillars of Information Providers and Educational Quality Control Activities]. Jakarta: Prenadamedia Group.

ŽivkoviL, S. (2016). A model of critical thinking as an important attribute for success in the 21st century. Procedia-social and behavioral sciences, 232, 102-108. 